\section{Europas Chicago}

\author{
København 1944-45
}

Afcand.mag. Henrik Lundtofte

"At den hemningslose Underverden, der ikke langere holdes i Tomme af de danske Sikkerhedsorganer, samtidig foranstaltede Blodorgier afMord paa Danske, har vi Tyske iagttaget med Beklagelse og haabet, at den offentlige Mening omsider ogsaa vilde reagere derimod... Men naar Underverdenens Elementer nu-enten paa udenlandsk Ordre eller af politisk Spekulation - i de sidste Dage paany er begyndt at angribe tyske Interesser, skal de og den danske Offentlighed vide, at heroverfor vil der blive reageret hurtigt og skarpt fra tysk Side ... ogsaa Befolkningen maa have en Interesse i, at enhver Slagkraft omsider beroves Underverdenen. At den hidtidige Kulturby Kobenhavn i dette Øjeblik overfor hele Verden staar som et europaisk Chicago, er bestemt ikke i det danske Folks og den danske Stats Interesse".

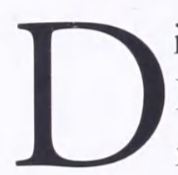
isse udtalelser fremsatte Werner Best, den tyske rigsbefuldmægtigede i Danmark, i slutningen af april 1944 overfor danske pressefolk. Ordene blev optakten til en mindre bølge af henrettelser. Best skiftevis truede befolkningen og appellerede til den om at tage afstand fra "underverdenen", hvormed han mente modstandsbevægelsen. Det var et bevidst led i propagandaen, når besættelsesmagten forsøgte at inkriminere og mistænkeliggøre modstandsbevægelsen ved at omtale den som "underverdenen" og dens medlemmer som "forbrydere". At udråbe København til et europaisk Chicago var derfor endnu et element i bestræbelserne på at vende opinionen imod modstandsbevægelsen.

Alligevel kan man undre sig over, hvorfor Best drog paralleller mellem det fredelige København og så Chicago, selve symbolet på den moderne, lovløse storbyjungle med Al Capone og snigmord, bankrøverier og blodige bandeopgør. $\mathrm{Og}$ hvordan kunne Best overhovedet forvente, at hans udmeldinger bare tilnærmelsesvist harmonerede med befolkningens oplevelse af tilstandene?

Skærpelsen af tilstandene i Danmark i 1943-45 med indførelsen af tyske terrormetoder har længe været negligeret af forskningen. Det har i de senere år ført til en udbredt opfattelse af besættelsen som en tid, hvor danskerne i fredsommelig kynisme frådsede, mens verden udenfor kæmpede, led og sultede. Men skønt omfanget forblev langt mindre end i samtlige andre tyskbesatte lande, var mord og terror også en del af besættelsens virkelighed. Og som om det ikke var nok, skabte mangelvaresituationen og tyske tiltag samtidig en eksplosion i kriminaliteten. Derfor er Werner Bests karakteristik af København trods alt ikke helt ude af trit med tilstandene i de sidste besættelsesår. Ingen trykte kilder demonstrerer hovedstadens Chicago-agtige præg tydeligere end Daglige Beretninger om Begivenheder under den tyske Besattelse. Det var fortrolige meddelelser, der blev udgivet af Københavns Magistrat og siden af Overborgmesterens kontor. Fra januar 1944 til maj 1945 holdt meddelelserne kommunens politikere og embedsmænd ajour med udviklingen i København og i provinsen. Dag efter dag bringer Daglige Beretninger 


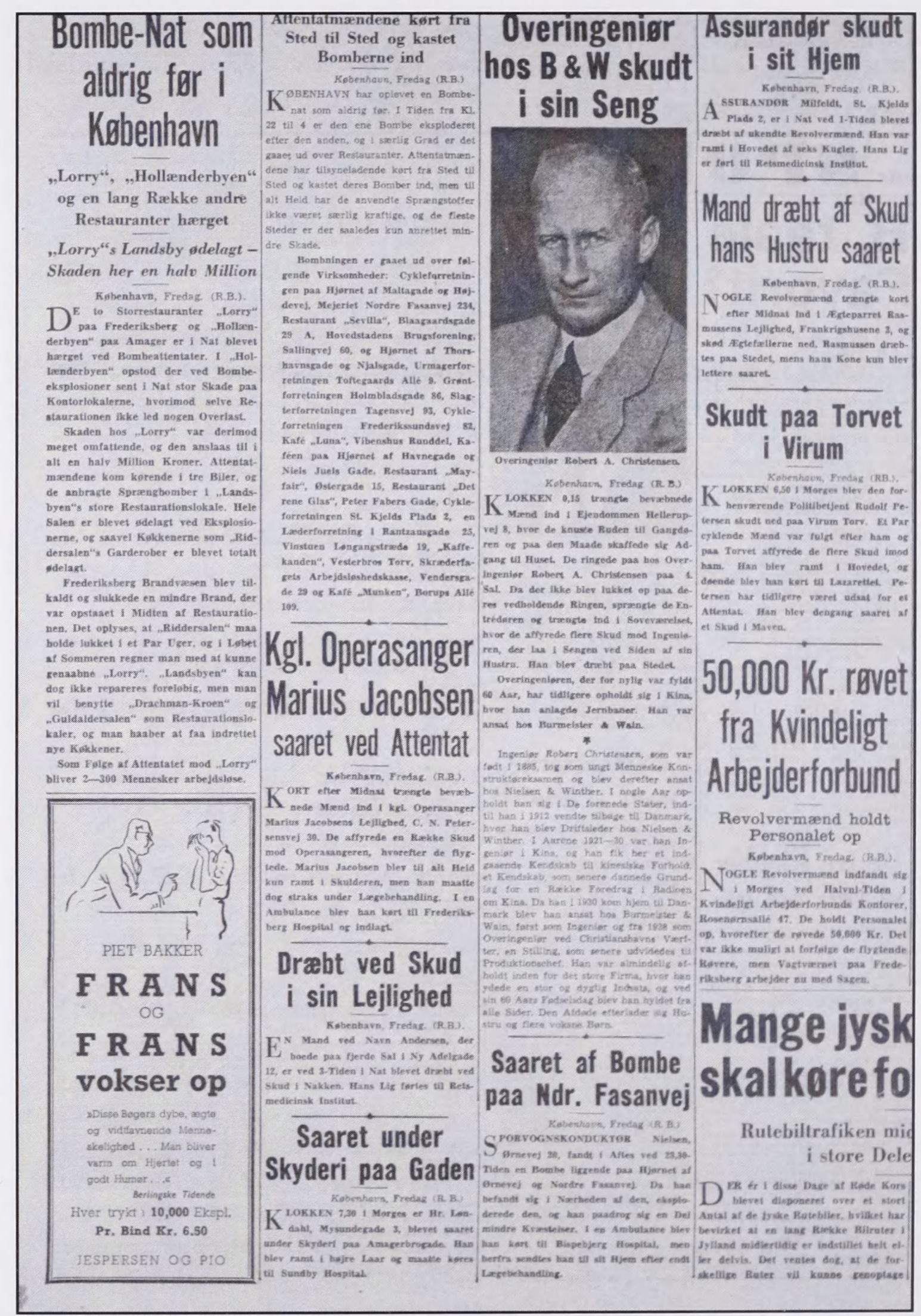

En avisside fra Politiken den 21.4.1945 der afspejler tilstandene $i$ de sidste måneder af besattelsen, da de var allermest skarpede. Efter drabet på Hipochefen Erik V. Petersen den 19. april begik medlemmer af korpset og grupper med tilknytning til Hipo en rakke gengaldelsesdrab og-sprengninger natten til den 20. april. Hvortil altså kom den upolitiske men grove kriminalitet. (Det Kongelige Bibliotek.) 
vidnesbyrd om røverier, attentater og mord. Undertiden er oplysningerne upålidelige, men alt $i$ alt giver beretningerne et unikt indblik i tilstandene i København 1944-45.

\section{Flødeskumsfrontens forvandling}

"An der Schlagsahnefront", ved flødeskumsfronten, noterede en tysk Gestapomand under et privatfoto fra København. Det var eftertragtet at gøre tjeneste i det besatte Danmark, hvor vareudbuddet var relativt rigeligt og tilstandene fremfor alt fredelige. Landet indtog en særstilling i det tyskbesatte Europa: Den 9. april 1940 accepterede regeringen at nedlægge våbnene, og til gengæld anerkendte Tyskland fortsat Danmark som en suveræn stat. Der var tale om et dansk-tysk interessefællesskab, der udmøntede sig i samarbejdspolitikken. Den danske regering styrede landet, retspleje og politi var på danske hænder, og besættelsesmagten behøvede til gengæld kun at anvende minimale ressourcer på Danmark. Samtidig kunne Tyskland udnytte besættelsesordningen propagandistisk og lukrere på en efterhånden vital fødevareeksport fra Danmark.

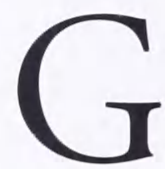
rundlæggende hvilede samarbejdspolitikken på den racistiske, nazistiske ideologi, der placerede danskerne blandt arierne. Dernæst hvilede den på ro og orden. Men med de tyske nederlag ved fronterne voksede modstandsbevægelsen frem, og tilstandene ændredes langsomt for at kulminere i Augustoprøret 1943, der førte til samarbejdspolitikkens fald. Regeringen gik af, og Best besluttede at indsætte et udøvende tysk politi. Dermed etablerede det frygtede og allerede dengang myteomspundne Gestapo sig i Danmark i september 1943.

Gestapos organisation var præget af det samme personaleunderskud som i andre besatte lande - blot et par hundrede Gestapofolk kom til Danmark i efteråret 1943. Deres virksomhed var fra begyndelsen præget af en indre modsætning mellem mål og midler. På den ene side skulle modstandsbevægelsen elimineres, men på den anden side måtte bekæmpelsen ikke forårsage en yderligere skærpelse af situationen. Danmark indtog stadig en særstilling, men dens fundament blev udsat for stadig sværere rystelser.

Den 27. oktober 1943 eksploderede en tidsindstillet bombe i københavnercafeen Mokka, der var populær blandt tyskerne. Tre tyskere og en dansk kvinde blev dræbt, og omkring 40 danskere og tyskere blev såret. I det øvrige tyskbesatte Europa medførte lignende attentater summariske massehenrettelser, men besættelsesmagten nøjedes med at idømme København en bod på 5 millioner kroner, dekretere udgangsforbud fra kl. 20 til kl. 5 og aftenlukning af byens forlystelsessteder.

Attentaterne mod tyskere fortsatte dog ligesom stikkerlikvideringerne. I begyndelsen af december 1943 blev en befalingsmand skudt ned på Jarmers Plads få hundrede meter fra det tyske hovedkvarter på Dagmarhus. Nu blev den tyske reaktion anderledes brutal. Gestapo afhentede tre modstandsfolk i Vestre Fængsel og likviderede dem på ladet af en lastbil i Ingerslevgade-skudt "under flugtforsøg" hed det.

Drabet på Jarmers Plads er omtalt i Josef Goebbels' dagbog, og likvideringen af de tre modstandsfolk var resultatet af, at den øverste nazistiske ledelse nu krævede helt andre og strengere repressalier i Danmark. Hitler var stærkt utilfreds med udviklingen og beordrede den 30. december Werner Best, von Hanneken, chefen for Værnemagten, og Günther Pancke, chefen 
for det tyske politi og SS i Danmark, til førerhovedkvarteret. Hitler forlangte repressalierne sat i system i form af gengældelser for hver likvidering og hver sabotage, modstandsbevægelsen foretog - øje for øje, tand for tand. Og for at undgå at der opstod "martyrer" krævede Føreren, at gengældelserne var anonyme. Resultatet var "modterror-aktioner" kendt som clearingdrab og schalburgtager. Digterpræsten Kaj Munk blev den 4 . januar clearingdrabenes første dødsoffer.

\section{Vendettaen}

"Kl. 15,08 blev Guldsmed Palle Skaanstrom drabt ved Skud i Ejendommen Kultorvet Nr. 13, 3. Sal." (Daglige Beretninger 1.-

2.8.1944.)

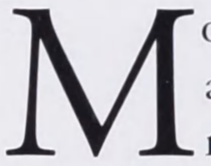
ordet på Skaanstrøm var efter alt at dømme gengældelse for modstandsbevægelsens likvidering af en nationalsocialistisk urmager i Sct. Paulsgade dagen forinden. Det særlige ved clearingdrabet på Guldsmed Skaanstrøm var, at dansk politi straks pågreb gerningsmændene, danske SS-folk. De måtte dog lige så hurtigt udleveres til det tyske politi.

Terrorhandlingerne fandt sted parallelt med, at dansk politi fungerede og jagtede enhver drabsmand - i nogle tilfælde altså Hitlerregimets statsterrorister! Besættelsesmagtens terror var derfor ikke kun anonym p.g.a. Førerens udtrykkelige krav men var tilpasset Tysklands fortsatte behandling af Danmark som et særtilfælde, idet de tyske myndigheder stadig prioriterede ro og orden og samarbejde med danske myndigheder højt.

Denne dobbelthed mellem fordækt, gangsteragtig terror og mere traditionelle metoder var specielt udtalt i Danmark, selv om de tyske repressalier i flere andre nord- og vesteuropæiske lande omkring 1943 også blev suppleret med rene terroraktioner.

Modterrorens karakter resulterede i en vendetta-lignende konflikt, en blodfejde, fordi clearingdrabene og schalburgtagerne i varierende forhold gengældte modstandsbevægelsens likvideringer og sabotager. Således skabte den tyske terror og den skærpede kamp mellem Gestapo og modstandsbevægelsen fra slutningen af 1943 grundlaget for en i princippet uendeligt accelererende voldsspiral. Og såvel i modstandsfolkenes rækker som i de tysk-danske terrorgrupper fandt der i tiden frem til befrielsen en tydelig brutalisering og professionalisering sted.

Hvad der imidlertid mere end noget andet tilfører konfrontationen sit anstrøg af vendetta er dens afgrænsning. Selv om clearingdrab og schalburgtager i løbet af 1944 i stigende omfang ramte uskyldige, udeblev den fuldstændig vilkårlige terror. I stedet blev ofrene på begge sider udvalgt på baggrund af deres reelle eller indbildte virksomhed for modstandsbevægelsen eller besættelsesmagten - eller p.g.a. deres tilhørsforhold til "den anden familie" så at sige. På tysk side blev ofre og mål udvalgt af Gestapos øverste chefer, og udvælgelseskriterierne var efter drabet på Munk primært geografiske. Et stikkerdrab på en dansk Gestapomand i København, medførte altså et clearingdrab i samme by. I visse tilfælde, drabet på Guldsmed Skaanstrøm er et eksempel, blev ofrene udvalgt p.g.a. deres profession, og i nogle få tilfælde fordi de opholdt sig, hvor en tysk soldat var blevet skudt ned. Ofrene for clearingdrabene var således langt fra kun fremtrædende personligheder og nationale koryfæer.

Clearingdrabene var et signal til 


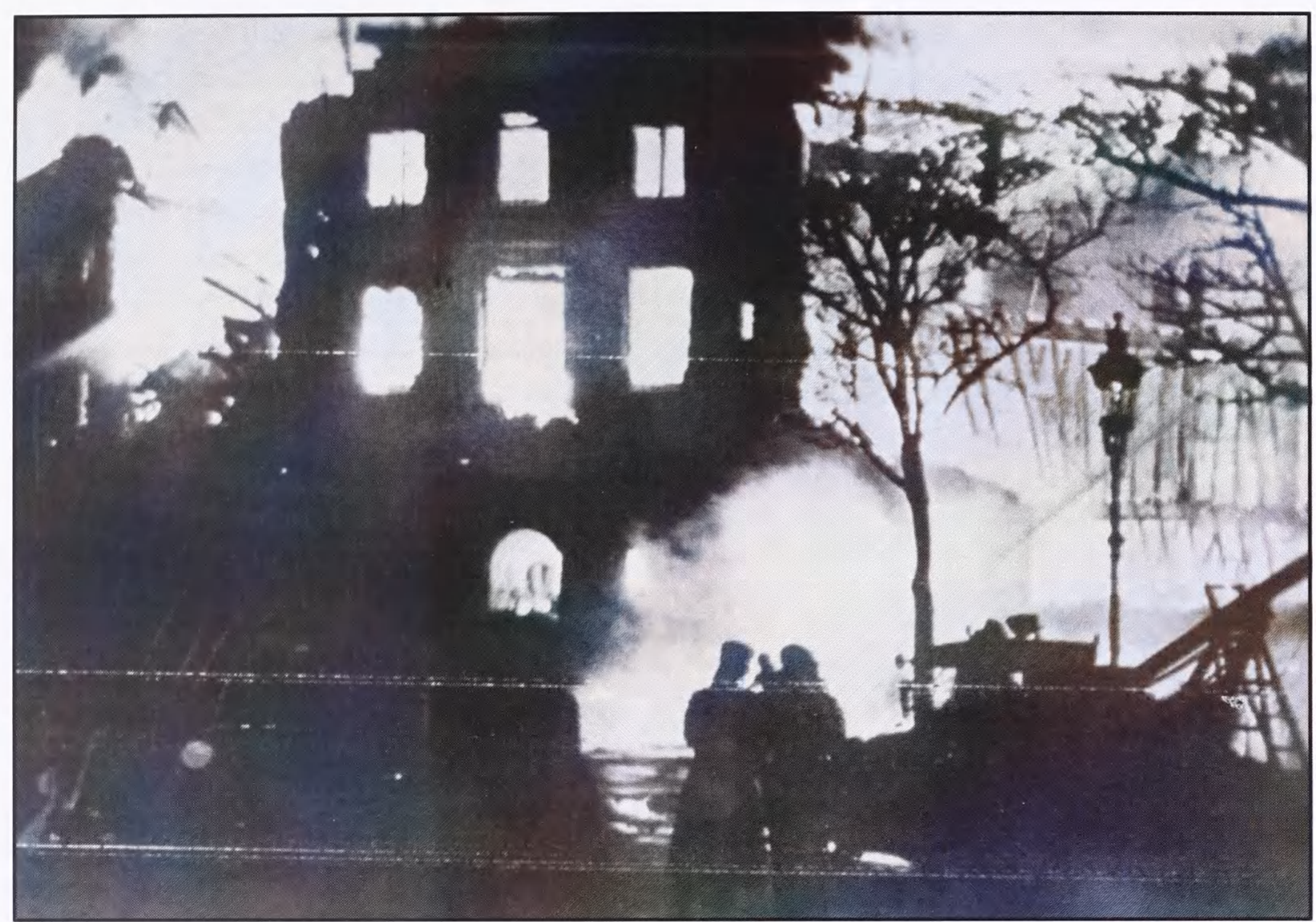

19. december 1944. OKs hovedsade i Holbergsgade bronder efter en Schalburgtage udfort af danske og tyske medlemmer af Petergruppen, der gennemforte langt de fleste modterroraktioner. (Det Kongelige Biblioteks Billedsamling.)

modstandsbevægelsen om omkostningerne ved sabotager og likvideringer og en demonstration af den tyske gengældelsesvilje. Desuden var det tyskernes formål at afskrække befolkningen fra at støtte og bistå modstanden. Modsætningen er til at få øje på, for anonym terror kunne der selvfølgelig ikke være tale om, når den samtidig skulle være et umisforståeligt signal. I afskrækkelseselementet er der i øvrigt en parallel til stikkerlikvideringerne, for skønt modstandsfolkene anså likvideringerne som et nødvendigt forsvar mod Gestapos optrevlinger, var aktionerne også blodige advarsler imod at entrere med besættelsesmagten.

Af meddelelserne i Daglige Beretninger kan man følge vendettaen accelerere til en ren voldsspiral. Modstands- bevægelsen begik stikkerlikvideringer på åben gade, og som taget ud af en gangsterfilm kørte modstandsfolk i nogle tilfælde op på siden af biler ført af danskere i tysk tjeneste og gennemhullede køretøjerne med maskinpistoler. Og de tysk-danske terrorgrupper brød ind i private hjem og myrdede danskere i deres soveværelser og skød endnu flere ned på hovedstadens gader. Alene $\mathrm{i}$ februar 1945 blev der i København gennemsnitligt skudt og dræbt et menneske om dagen. Ved befrielsen havde vendettaen resulteret i over 100 clearingdrab i hele landet, hvortil kom snesevis af ofre for schalburgtagerne, mens modstandsbevægelsens likvideringer kostede over 400 livet.

Samtidig var kriminaliteten steget kraftigt, grove overfald og væbnede røverier hørte til dagens orden, og ikke så få 
af drabene i hovedstaden i det sidste besættelsesår var rene rovmord.

\section{Aktion Möwe og konsekvenserne}

"Allerede i Dag sporede man forskellige

Virkninger af, at Byen er uden Politi, saaledes

etpar Butiksplyndringer. Paa Gadehjornerpaa

Vesterbro og i den indre By kunde man overvare regulare Udbud fra Sortborsgrosserer $i$ Tobaksvarer. Fardselsreglerne respekteres heller ikke saa noje som tidligere ..." (Daglige

Beretninger 20.9.44)

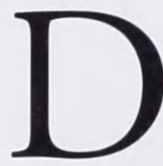

en 19. september 1944 havde

besættelsesmagten gennemført aktion Möwe, der havde til formål at reducere det velbevæbnede og talstærke danske politikorps. Små 2000 betjente blev sendt i koncentrationslejr. Resultatet blev, at den resterende politistyrke opløste sig selv. Henved 8000 betjente trak sig fra aktiv tjeneste. Udviklingen kom bag på den tyske ledelse, der langt fra rådede over ressourcer til at overtage mangfoldigheden af samfundsnødvendige opgaver. Og i slutningen af september er der flere eksempler i Daglige Beretninger på konsekvenserne for befolkningen. En forretningsmand henvendte sig på politistationen på Nytorv, men hans tyverianmeldelse blev afvist - "det har vi skam slet ikke mandskab til" lød begrundelsen. Og da en kvinde ville anmelde et røveri, fik hun besked på, at det tyske politi ikke kunne påtage sig at være

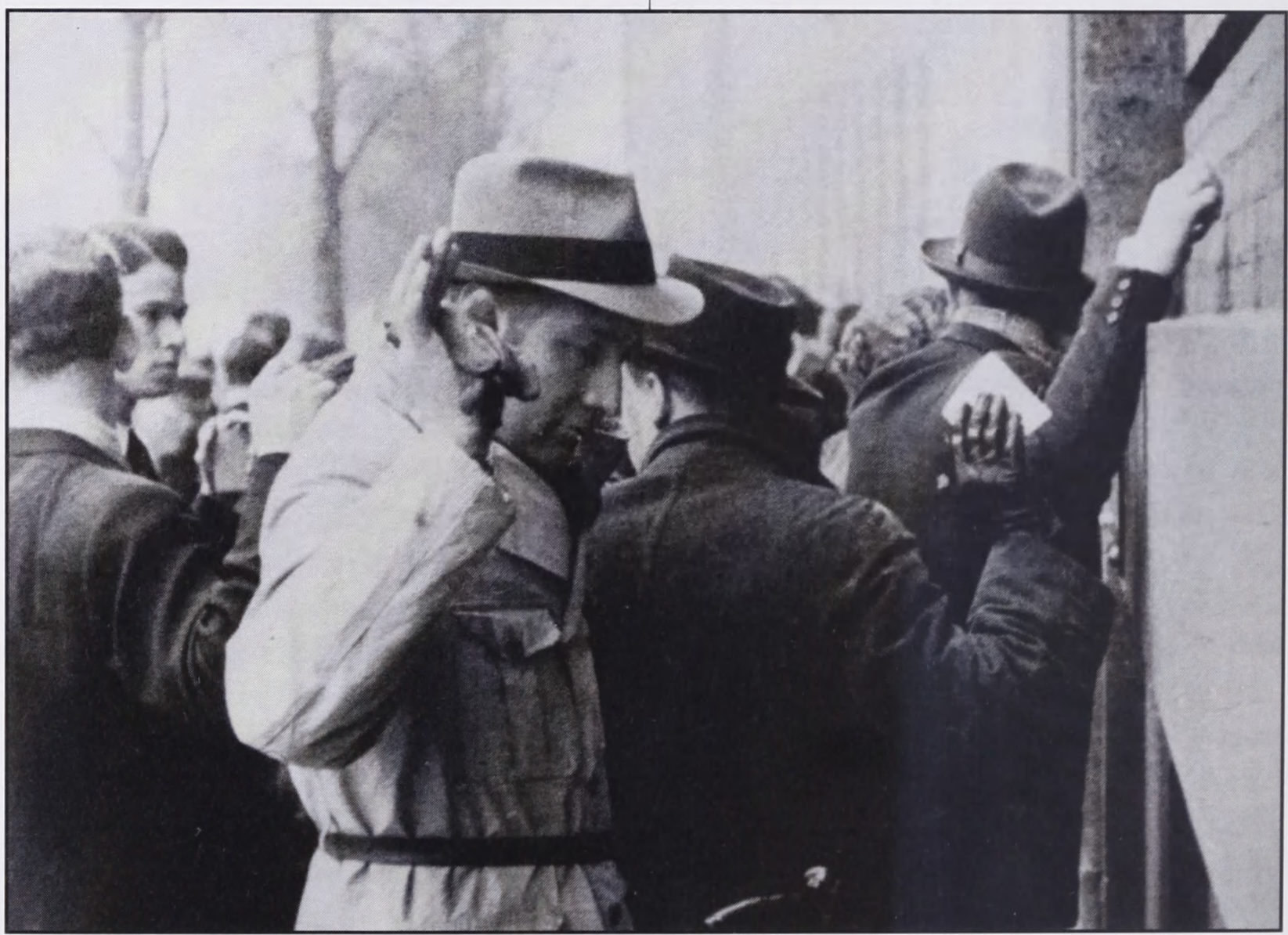

Det tyske politi foretog ikke sjaldent store gaderazziaer, hvor tilfaldigt forbipasserende blev gennet sammen og fik kontrolleret deres papirer. Ved hjalp af denne metode paggreb Gestapo undertiden modstandsfolk eller fra efteråret 1944 "asociale" og "vanekriminelle". Tid og sted for denne razzia erukendt. (Det Kongelige Biblioteks Billedsamling.) 
barnepige for folk.

Tyskerne oprettede et dansk hjælpepoliti, Hipokorpset, men korpset blev primært sat ind imod den voksende modstand. Besættelsesmagten tillod i oktober desuden etableringen af kommunale og private vagtværn, der ubevæbnede og uerfarne ikke sjældent stod chanceløse overfor revolver-hold-ups og hærdede forbrydere. Reelt var Danmark fra efteråret 1944 til maj 1945 uden et egentligt politi.

Denne for et moderne samfund helt usædvanlige situation førte straks til en eksplosion i kriminaliteten, der i forvejen var højere end i fredstid. Krisekriminaliteten, bl.a. sortbørshandlen, florerede og involverede også ellers lovlydige danskere, som Claus Bundgaard Christensen for nylig har påvist. Også den alvorlige kriminalitet steg kraftigt. I hele 1939 fik Københavns politi 10 røverianmeldelser. I 1943 var antallet steget til 116. Alene i november $1944 \mathrm{blev}$ der ifølge daværende statsadvokat Jørgen Trolle begået omkring 100 røverier i hovedstaden og i januar 1945 over 200. Tallene skal tages med forbehold. Men de giver dog et klart billede af en eksploderende vækst i kriminaliteten, som bekræftes af Daglige Beretninger, der endda langt fra omtaler alle forbrydelser.

Besættelsesmagten havde med politiaktionen forsøgt at eliminere muligheden for at dansk politi kunne falde den $\mathrm{i}$ ryggen under en invasion. Men i stedet havde den fåt skabt en syndflod af nye problemer, der endog truede den ro og orden, som i sidste ende var en forudsætning for bl.a. fødevareeksporten til Tyskland. Det tyske politi greb hurtigt til radikale metoder. Torsdag den 29. september meddelte Daglige Beretninger, at tysk politi natten til onsdag havde foretaget en stor razzia i København. Flere hundrede blev arresteret i deres hjem, i suppekøkkener og på værtshuse.

Razziaen var startskuddet til en bekæmpelse af kriminaliteten, der var stærkt præget af nationalsocialistisk tankegang. Gennem sit pressekontor erklærede politichefen, Günther Pancke, om de arresterede, at såfremt det drejede sig om "Vaneforbrydere eller asociale Elementer, vil disse ligesom Indbrudstyvene, Bedragerne og Alfonserne blive ført til en Koncentrationslejr i Tyskland". Kategorierne "asociale" og "vaneforbrydere" var hentet fra den kriminalitetsbekæmpelse, Hitlerregimet allerede havde begyndt i 1930erne. Efter racehygiejniske kriterier blev tusinder sendt i koncentrationslejre. Det var ikke kun ægte forbrydere men også subsistensløse, tiggere og mennesker, der i det hele taget afveg fra de nazistiske normer.

Mellem september 1944 og januar 1945 blev i alt 421 danske "asociale og vanekriminelle" sendt i KZ-lejr. Af dem omkom 62. Trods de hårdhændede tyske metoder var der ikke tale om en generaloffensiv mod kriminelle og normafvigere, men et forsøg på at afskrække og på at vise handlekraft overfor den danske befolkning. Desuden blev razziaerne mod "vanekriminelle" brugt i den tyske propaganda til at udviske skillelinien mellem forbrydere og modstandsfolk.

Fra dansk side reagerede anklagemyndighederne, der ligesom fængselsvæsenet stadig var i funktion, på kriminalitetsstigningen ved i oktober at kræve 3-4 gange strengere straffe for forbrydelser begået under de politiløse tilstande. Hverken disse tiltag eller udsigten til KZ-ophold satte imidlertid en stopper for hold-ups og tyverier. 


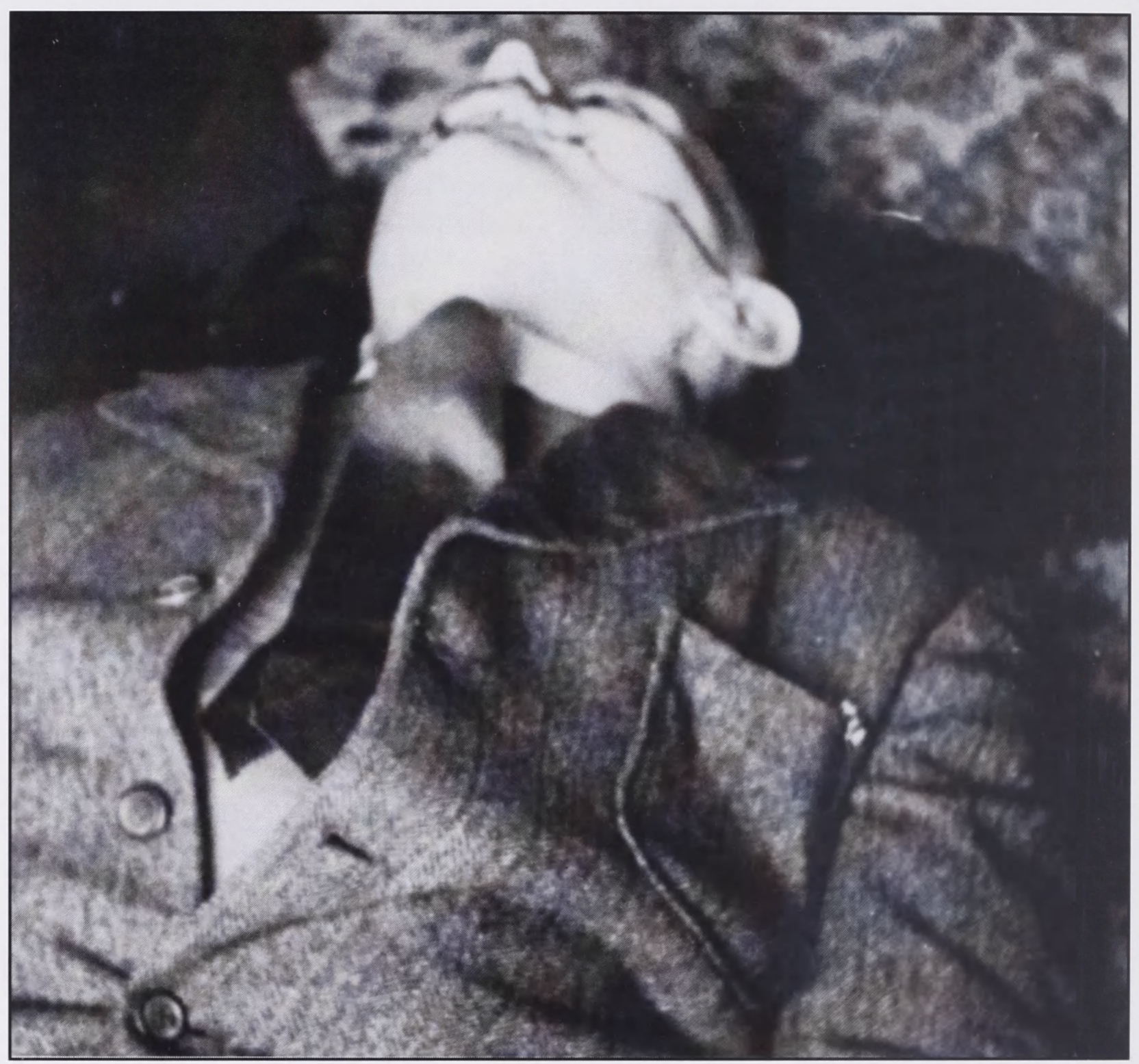

Foto fra maj 1945 der angivelig viser en drabt stikker. (Det Kongelige Biblioteks Billedsamling.)

\section{Politiløse tider}

"Farlige Forbrydere anholdt. De danske Myndigheder er for Tiden ved at rulle en meget farlig Forbryderbande op. Det drejer sig om Forbrydere, der under Foregivende af, at de kom fra Shellhuset, trangte ind i private Lejligheder og sagde, at de skulde eftersøge illegalt Materiale". (Daglige Beretninger 2.1.45.).

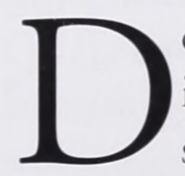
en omtalte forbryderbande var ikke den eneste, der ved at udgive sig for Gestapo, berøvede folk deres værdier. Kriminelle udnyttede i det

hele taget den generelle utryghed og fraværet af et egentligt politi. Og samtidig opstod der organiserede bandenetværk af hidtil ukendt rå og omfattende karakter. Den fra romaner og TV-serier velkendte forbryder Edderkoppen og andre kriminelle slog ikke kun deres folder i efterkrigstiden men lagde netop grunden til deres storkriminalitet under besættelsen.

Væbnede røverier af store pengesummer, tyverier (sågar af Røde Korspakker), og hold-ups på de københavnske gader greb om sig. Den florerende pengeafpresning er et andet konkret eksempel på 
kriminelles udnyttelse af de politiløse tilstande. Nogle afpressere udgav sig for modstandsfolk og forlangte store beløb for ikke at sprænge butikker i luften eller endog likvidere indehaverne. Flere kendte forretningsfolk, læger og advokater modtog trusselsbreve, der lovede store ubehageligheder, såfremt modtagerne ikke betalte. Selv den tyske modterror blev brugt som afpresningsmiddel. I april 1945 udnyttede to yngre mænd clearingdrabene på flere læger ved at true en københavnsk overlæge med samme skæbne. Begge afpressere blev dog ifølge Daglige Beretninger anholdt af det kommunale vagtværn.

En betydelig del af røverierne blev begået af modstandsfolk, der havde brug for f.eks. køretøjer. For den store del af befolkningen var det næppe let at skelne mellem motiverne der lå til grund for de kriminelle handlinger, og der fandtes faktisk folk i modstandsbevægelsens rækker, der bevidst overskred grænsen mellem modstandskamp og ordinær berigelseskriminalitet. Også på den anden side supplerede nogle af Gestapos danske håndlangere en i forvejen udmærket løn med tyverier fra arrestanter. Deres berigelser nåede dog sjældent det enorme omfang, rygterne og efterkrigstiden malende berettede om.

De politiløse tilstande medførte mange tilfælde af selvtægt, der især fandt sted i ugerne mellem opløsningen af politiet den 19. september 1944 og oprettelsen af de kommunale vagtværn i løbet af oktobernovember samme år. Med vareknapheden var selv ellers ret uskyldige tyverier af vasketøj eller cykler alvorlige nok og førte ofte omgående til uddelinger af tørre tæsk. Mere organiserede men temmelig alternative afstraffelsesformer blev også resultatet af de politiløse tider: Arbejdere og lærlinge "ryddede op" i sortbørshandelen med knytnæverne, mens Koldings borgmester lod medlemmer af den lokale bokseklub prygle sortbørshajerne!

Udviklingen i 1944-45 satte skel tværs gennem Danmark. På landet herskede der stadig nogenlunde normale tilstande, men i de største provinsbyer og især i hovedstaden var mord, terror og grove røverier efterhånden blevet dagligdag. Det er dog vanskeligt præcist at vurdere, hvordan storbybefolkningen lod sig påvirke af tilstandene. På den ene side kan man konstatere, at folk ikke blev hjemme, biograferne havde stadig fulde huse i 1944 45. Men på den anden side er der klare vidnesbyrd om en betydelig utryghed. Kort efter den tyske aktion mod politiet florerede rygter om massevoldtægter begået af tyske soldater. Rygterne var dog uden hold i virkeligheden og blev hurtigt dementeret. Aftenskoler flyttede deres undervisning til dagstimerne, og nogle steder blev der organiseret grupper af yngre mænd, der skulle følge kvindelige elever sikkert hjem. Og i aviserne dukkede der pludselig annoncer op, der averterede med hårdtslående gummiknipler "til selvforsvar".

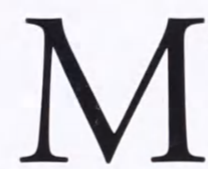

angelvaresituationen og ikke mindst opløsningen af det danske politi i 1944 førte til grove, organiserede kriminalitetsformer - der var unægtelig langt fra pengeafpresningen, revolverrøverierne og rovmordene i besættelsens slutfase til det Borende X, mellemkrigstidens fredsommelige gentlemantyv. Samtidig rullede en terrorbølge over landet, som grundlæggende forvandlede Flodeskumsfronten. Antallet af danske ofre for den tyske terror var dog yderst minimalt set i forhold til niveauet mange steder i det øvrige besatte Europa og 
den relativt lave terrorvirksomhed var et udslag af en klar og unik tysk moderation. Til gengæld medførte modterroren med dens snigmord og modstandsbevægelsens likvideringer en vendetta-lignende konflikt, der sammen med kriminalitetseksplosionen resulterede i tilstande i København, der måske ikke ligger så langt fra populærforestillingerne om tyvernes og tredivernes Chicago.

\section{Litteratur}

Bundgaard Christensen, Claus: Krisekriminalitet i Danmark - en undersøgelse af domsudskrifter fra Københavns Byret 1939-1944. "Kriminaliteten er ikke hva den var" - Avviket i historisk lys. 2000, s. 67-75.

Christiansen, K. O.: Kriminalitet i Danmark fra 1937 til 1948. H. Takala og H. Tham (red.): Krig og moral. 1987, s. 21-40.

Daglige Beretninger om Begivenheder under den tyske Besattelse. Fra Januar 1944 til Maj 1945. Udg. af Overborgmesterens Sekretariat. 1946.

Horwitz, Hugo: En sabotors erindringer. 1964. Larsen, Melchior: Københavns Kommunes Vagtværn. Sigurd Thorsen (red.): Kobenhavns Vagtvarn 1944-1945. 1947, s. $77-$ 330.

Lundtofte, Henrik: Gestapo. Kommende udgivelse på Gads Forlag..

Trolle, Jørgen: Syv Maaneder uden Politi. 1945. 